\title{
Methane gas hydrates influence on sudden coal and gas outbursts during underground mining of coal deposits
}

\author{
Volodymyr Bondarenko ${ }^{1}$, Olena Svietkina ${ }^{2}$, Roman Lysenko ${ }^{1 *}$, and Baochang Liu ${ }^{3}$ \\ ${ }^{1}$ Dnipro University of Technology, Department of Mining Engineering and Education, 19 Yavornytskoho, \\ 49005 Dnipro, Ukraine \\ ${ }^{2}$ Dnipro University of Technology, Department of Chemistry, 19 Yavornytskoho, 49005 Dnipro, Ukraine \\ ${ }^{3}$ Jilin University, College of Construction Engineering, 2699 Qianjin St., 130000 Chaoyang Qu, \\ Changchun Shi, Jilin Sheng, China
}

\begin{abstract}
The mechanism of gas hydrates formation in coal seams is studied in the paper, as well as their involvement is hypothesized in the sudden outbursts of coal and gas during underground mining of coal deposits. It has been substantiated and proved that one of the real reasons for subsequent outbursts is the formation of gas hydrates in coal as a type of secondary gas hydrate deposits. It has been also substantiated that, as a result of coal metamorphism, a large amount of gaseous hydrocarbons, mainly methane, is formed in the seam, which under certain thermobaric conditions leads to the gas hydrates formation. It has been experimentally proved that the mechanism of such inclusions formation between gas hydrate and coal is a result of strong chemisorption, which, when disturbing thermobaric conditions, leads to gas-dynamic activity of coal seams. It has been revealed that during the dissociation of gas hydrates, obtained in a medium of activated coals, twice as much gaseous methane is released. The research analysis indicates that the formation of natural gas solid solutions in coal pores under certain thermodynamic conditions and the natural humidity, characteristic of coal seams, is one of the causes of sudden coal and gas outbursts. The gas hydrates dissociation influences on the gas-dynamic activity of a coal seam and the formation of an outburst hazardous situation.
\end{abstract}

\section{Introduction}

The work in coal mines of Ukraine is executed in difficult conditions, the gas-bearing and outburst hazardous seams are being mined on a practical level. The characteristic of such developments is as follows: the average depth of mining exceeds $725 \mathrm{~m}$, and 30 mines operate at a depth of $1000-1400 \mathrm{~m}$. Most of the mines are gas mines (about 90\%), 60\% are mining the seams that are hazardous due to dust explosions, $45 \%$ are hazardous due to sudden outbursts, and $25 \%$ are hazardous due to spontaneous coal combustion [1].

As a rule, the largest number of ignitions of methane-air and dust-air mixtures occurs in such mines, which often leads to disaster. Over the past five years, large-scale disasters

\footnotetext{
*Corresponding author: rom.lysenko.23@gmail.com
} 
have occurred in Russia, Ukraine and Kazakhstan at the "Ul'yanovskaya", "Yubileynaya" and "Raspadskaya" mines in Kuzbass, at the "Named after A.F. Zasiadko" PJSC, "Named after K. Marx", "Suhodolskaya" and "Abayskaya" mines in Karaganda, which killed more than 500 miners. The explosion products and the shock wave broke to the surface and destroyed the mine surface buildings of both vertical shafts. The extent of these accidents have caused a great public outcry, and mining experts had many problematic questions about the prospects for the further development of coal industry in the conditions of methane and coal dust ignition. This issue was actively discussed in the framework of the conference "Ukrainian School of Mining Engineering - 2019" [2 - 4].

There are many assumptions about the causes of the explosion and the explosive situation in the mines. Undoubtedly, these processes are related to the mechanochemical processes of decomposition of an organic hydrocarbon coal substance consisting of macromolecules. Coal macromolecules can easily collapse and generate saturated and unsaturated hydrocarbons $\left(\mathrm{CH}_{4}, \mathrm{C}_{2} \mathrm{H}_{6}, \mathrm{C}_{2} \mathrm{H}_{4}, \mathrm{C}_{2} \mathrm{H}_{2}\right)$, hydrogen, carbonic oxide, and coal dust nanoparticles. In the products of coal substance decomposition, radicals are formed that cause chain reactions, resulting in the formation of methylene $\mathrm{CH}_{2}$, which is an active radical of divalent carbon [5]. This radical forms acetylene - one of the most powerful chemical explosive compounds, which differs from others in extreme unsustainability and instability. Acetylene causes spontaneous explosions of acetylene-methane-hydrogen mixtures without the participation in this process of any sources of initiation (ignition) or even atmospheric oxygen [6]. The formation of methyl groups $-\mathrm{CH}_{3}$ in coal substance macromolecules leads to the fact that when the coal substance is destructed, its half-decay products and coal dust nanoparticles are generated with $\mathrm{CH}_{3}$ methyl radicals adsorbed on the particles surface. They easily enter into the chain reactions with atmospheric oxygen; in this case, heat is generated and self-ignition of the dust-air mixture occurs.

However, one more reason should be considered, which explains the methane occurrence during the coal mines operation in such difficult conditions. This reason is the natural methane gas hydrates formation during the process of minerals evolutionary depositing, that is, in the process of coal substance metamorphism, gaseous hydrocarbons are formed, mainly methane. The amount of methane generated during the formation of one ton of bituminous coal is measured (under standard conditions) in hundreds of cubic meters [7]. Part of the gas is weathered or carried away with fluid flows filtering the seam, and part remains. Methane fills the free pore space of coal, is adsorbed on the pores walls, and dissolves in the solid coal substance [8]. Despite many years of research on the methane interaction with coal, some issues have not yet been thoroughly studied [9]. In the process of coal mining operations, the methane emitted makes mine air explosive, affecting $[10-12]$ on the productivity and safety of mining operations.

For the first time, the gas hydrates formation in coal seams was studied by Yu. Makagon in $[13,14]$.

In the works [14-16], the conditions are studied of formation, stable existence, and properties of hydrates under natural conditions in different terrestrial areas and in the World Ocean. It has been revealed that thermodynamic conditions alone, such as temperature and pressure, are not enough for the gas hydrates existence. It is also required a high content of organic substance in the rocks (from 0.5 to $4 \%$ and above), the active generation and migration of hydrocarbons to the hydrate formation zone. Young coals at the very beginning of metamorphism are such a favourable environment.

The process of gas hydrates formation in nature refers to the deep-laid type, that is, gas particles are held and move in the volume of near-bottom soil. At the same time, the filtration-volumetric parameters of the rocks containing the gas are changed significantly [17]. The gas hydrates in natural conditions are formed by two mechanisms:

1. Gas hydrates are formed at the contacts of grains, which are the weakest 
structural elements.

2. Gas hydrates cement the sediment matrix, being formed in the pores outside the contacts between the grains, therefore they weakly or not influence on the rock particles cohesion, which leads to a decrease in sediment porosity.

The results evidence that crystalline hydrate is a separate phase included into the pore, which reduces the rock porosity. However, these results are obtained only for synthetic surfaces, the properties of which are close to quartz [18]. Underground water and the resulting various gases are permanent components that will form hydrates under certain conditions.

Secondary deposits of gas hydrate are located on the continents. They are formed under impermeable lithological coverings with the availability of free gas. During the geological time of the Earth's existence, a cyclic change in temperature occurs in the coal rock section, which leads to phase transitions and, thus, gas hydrates are accumulated in the coal rocks [19-21].

Recently, the research has appeared which studies the possibilities to use coal matrices as carriers of gas hydrates [22]. Because of the high gas-bearing capacity of the hydrate form and, at the same time, the extremely slow process of the gas hydrates formation from large drops of water, a search is underway for the systems with a large area of water-gas interphase boundary. There is a series of studies dedicated to activated coals.

Based on the research into the gas hydrates formation in various rocks, it has been found that there is a change in the gas composition from methane to other homologues [23-25]. Thus, the results of fundamental studies of the gas hydrates formation mechanism, as well as data on the influence of mechanically activated additives on the hydrate formation process, indicate the possibility of the gas hydrates existence in coals. Due to the complexity of the experimental nature, the hydrate formation mechanism is not well studied. Nevertheless, study of the mechanism of gas hydrates formation in the conditions close to natural is a required condition for improving the technology of safe mining of minerals [26].

As a result of research, it has been found that during the gas hydrates formation on activated aluminium silicates, the cryochemical synthesis of hydrocarbons occurs [27], which is caused by formed additional reaction centres during activation. This indicates a change in the mechanism of gas hydrates formation in the course of the process. The constants of these reactions velocities have been determined. Using the chromatographic method, the ethane formation up to $5-6 \%$ has been determined. This indicates the possibility of gas hydrates formation in various rocks, including coal seams.

\section{Purpose and objectives of research}

The purpose of this work is to study the mechanism for producing the methane gas hydrates with a high content of hydrate-forming gas in the solid phase in an isolated system when changing the stress-strain state of the rock massif, entailing the sudden gas hydrates decomposition and, as a result, leading to sudden coal and gas outbursts. To achieve this purpose, the following tasks are set and solved:

- determine the influence of mechanically activated coals on the gas hydrate formation process;

- determine the composition of gas in the gas hydrates when conducting the process in the presence of activated coals.

\section{Results and discussion}

The synthesis of methane gas hydrates was conducted in a plant for the gas hydrates production, which makes possible to model thermobaric conditions similar to natural ones. The NPO-5 plant, designed at the Dnipro University of Technology (Dnipro, Ukraine), 
enables a research into the fast production of methane gas hydrates in "mild" conditions, varying the temperature (from +0.5 to $+10^{\circ} \mathrm{C}$ ) and pressure (from 1 to $10 \mathrm{MPa}$ ) $[28,29]$. Then, in accordance with the previously developed methodology [30], the chamber is filled with mechanically activated coal, and the process of obtaining methane gas hydrates is being started.

Grade $\mathrm{G}$ coals are used as mechanically activated coals. Mechanochemical activation of the materials is performed using the vertical vibration mill. Its main advantage is the reduction in time of the powders grinding, on the one hand, and, on the other hand, during vibratory-percussion activation, not only surface activation of the material occurs, but also an internal structure of the particles is disturbed. Thus, there is a penetration of the active zone to a great depth [31], which leads to bulk ionization of the activated material.

To determine the dispersion constant, a method is used for assessing the granulometric composition of powders by specific surface area, which is a convenient dispersion characteristic [32]. The specific surface is determined by the resistance of rarefied gas to filtration. The method is based on the theory of the rarefied gas flow through a system of solid balls, developed by B.N. Deryagin, that is, when the path length of gas molecules is much greater than the distance between the balls (Knudsenflow regime) [33]. Method error $-1 \%$.

The average size of the crushed particles is determined by the data obtained on a SK LAZER MICRON SIZER PRO-700 laser particle analyser (Japan). The formation of an activated state is closely related to the material energy characteristics [34]. In this regard, a universal method has been used to study the energy characteristics of materials by potentiometric measurements in suspensions with an indifferent electrode. The method of potentiometric measurements [35] enables calculating the potential curve and the total adsorption potential.

Diffractograms "in situ" were obtained on a DRON-2 X-ray diffractometer ("Burevestnik", Russia). The phase analysis of the materials was determined on a DRON-3 $\mathrm{X}$-ray diffractometer ("Burevestnik", Russia): radiation $\mathrm{Fe} K \alpha$, high voltage $35 \mathrm{eV}$, anode current of $20 \mathrm{~mA}$. The physical-chemical processes occurring during the methane gas hydrates production have been studied using the methods of differential thermal analysis (DTA) and X-ray fluorescence analysis (XRF). The composition of gaseous products has been studied using the method of gas adsorption chromatography on a LKhM-2000-TM chromatograph ("Electra", Russia).

At the first stage, artificial conditions for metamorphism have been created in which the structural characteristics of coals are changed. Grade G coals were studied experimentally, because it is this coal contains the majority of functional groups capable to be oxidized and join other polar molecules. Designations are adopted in the table: $V^{G}$ - volatile yield in the studied samples; $K^{G}$ mg-eq/100g of coal - the total content of phenolic and carboxyl hydroxyls according to GOST 8930-70; $S$ - specific surface; $W_{\max }$ - the amount of adsorbed water vapour on the samples at a partial pressure of vapour $P / P_{5}=1$ (desiccant method). Using the BET adsorption equation, $a_{m}$ is calculated - the amount of water required to cover $1 \mathrm{~g}$ of adsorbent (coal) with a monomolecular layer; $Q$ - thermal effect of wetting coals with water.

Grade $\mathrm{G}$ coal has the highest values of $W_{\max }, a_{m}, S$ and $Q$. The lowest content of functional groups in the coals. However, vibratory-percussion activation leads to the fact that after a 30-minute processing, there is a decrease in hydrophilic properties. As a result of coal activation, there is a restructuring in the coal substance, aimed at simplifying the structure and composition with a higher content of aromatic carbon, which leads to the occurrence of microscopic pores up to $1 \mathrm{~nm}$. In the last sample, there is some increase again in the number of functional groups, hydrophilic properties and the heat of wetting increases from 4.6 to $6.2 \mathrm{~J} / \mathrm{g}$. This fact can be explained by the peculiarity of the physical structure: amorphous carbon is exposed to graphitization and a crystal lattice of graphite is being generated. 
Table 1. Change in the physical-chemical properties of coal under vibratory-percussion loading.

\begin{tabular}{|c|c|c|c|c|c|c|}
\hline $\begin{array}{c}\text { Time of } \\
\text { vibratory- } \\
\text { percussion } \\
\text { activation, min }\end{array}$ & $V^{G}, \%$ & $\begin{array}{c}K^{G}, \mathrm{mg} \text {-eq } \\
\mathrm{KOH} / 100 \mathrm{~g} \text { of } \\
\text { sample }\end{array}$ & $S, \mathrm{~m}^{2} / \mathrm{g}$ & $a_{m}, \mathrm{~g} / \mathrm{g}$ & $W_{\text {max }}, \mathrm{g} / \mathrm{g}$ & $Q, \mathrm{~J} / \mathrm{g}$ \\
\hline 0 & 44.3 & 219 & 2.2 & 0.0143 & 0.0789 & 6.8 \\
\hline 10 & 32.8 & 120 & 2.9 & 0.0156 & 0.0824 & 5.9 \\
\hline 20 & 16.4 & 90 & 3.2 & 0.0189 & 0.0899 & 5.0 \\
\hline 30 & 11.9 & 40 & 3.4 & 0.0213 & 0.0933 & 4.6 \\
\hline 60 & 5.3 & 60 & 3.6 & 0.0289 & 1.0859 & 6.2 \\
\hline
\end{tabular}

From a physical point of view, coal moistening occurs in three stages: filling of fractures, capillary penetration into thin pores, diffusion impregnation. In this case, artificial moistening occurs due to the same forces as with the natural water sorption. Using the method of nuclear magnetic resonance, it has been determined that physical adsorption of water in mineral coals occurs through the lateral mobile aliphatic groups of the coal organic substance. With vibratory-percussion impact, the number of aliphatic groups decreases rapidly, the coal structure becomes more regular, water molecules penetrate into the ultrathin pores and voids between the main structural units of the coal substance and are bound to the backbone of aromatic grids. Thus, on the one hand, the effect of forming a coal matrix is achieved, and, on the other hand, there is porosity of a certain size.

The result of vibratory-percussion activation of coal is the formation of structural defects that change the bond nature between the adsorbed particle and the coal lattice. In this regard, with vibratory-percussion loading, a special form of chemisorption occurs. This form is called "strong". Moreover, the simultaneous existence is possible of both a "strong" acceptor form and a "strong" donor form. In the case of "strong" chemisorption, which occurs under vibrational loading, the gas molecules electrons are able to interact with the electrons of solid body atoms. As a result, gas molecules are fixed on the carbon surface and an adsorption layer is formed. In this case, chemical forces act, but this does not mean that the usual chemical compound has already formed. To form the latter one, it is necessary to destroy the bonds between the adsorbent atoms. Up to $10^{17}$ gas molecules can be adsorbed per $1 \mathrm{~cm}^{2}$ of surface, and in the case of physical adsorption (by monomolecular layer) this amount is two orders of magnitude less.

To confirm the effect of "strong" chemisorption, the thermal effects have been measured during the methane adsorption of ordinary physical and chemisorption, which occurs under vibratory-percussion impact on the samples. It is known that only physical adsorption occurs at low temperatures, therefore, the experiments were conducted at a low temperature of $293 \mathrm{~K}$. The results are presented in the Table 2.

Table 2. Change in thermal effects with coal activation in the presence of oxygen.

\begin{tabular}{|c|c|c|c|c|c|}
\hline Time of grinding, $t, \mathrm{~min}$ & initial & 15 & 30 & 45 & 60 \\
\hline Thermal effect, $\mathrm{J} / \mathrm{kg} \cdot \mathrm{mol}$ & 2.068 & 10.973 & 15.070 & 24.148 & 29.783 \\
\hline $\mathrm{O}_{2}, \%$ & 0.67 & 1.0 & 2.6 & 3.0 & 4.6 \\
\hline
\end{tabular}

Thus, under vibratory-percussion loading, the intermediate carbon-oxygen compounds are formed associated with the process of chemical adsorption. This behaviour can be explained by the "mosaic" nature of the coal activated surface after vibratory-percussion impact. This "mosaic" nature means that hydrophilic and hydrophobic hydrocarbon fragments alternate on the activated surface.

An interesting fact is that inorganic impurities of coals are also exposed to activation with a change in physical-chemical properties, which leads to a catalytic effect both for the process 
of structured dispersions formation and the process of fuel burning. Analysis of the experimental data on the adsorption of some inorganic electrolytes (in particular aluminium sulphate, the concentration of which is $1.0 \%$ ) depending on the time of vibratory-percussion loading evidences that there is a change in the adsorption capacity of aluminium sulphate.

The formation of an "active" methane on a coal surface in the form of carbonyl, carboxyl, and hydroxyl groups leads to an increase in the negative charge on the activated material. In this regard, there is a strengthening of electrostatic interaction between the aluminium cation and the "active" oxygen of the coal surface, and as a result, an increase in adsorption.

The adsorption of aluminium sulphate (located in groundwater) on the coal activated surface leads to a decrease in electrostatic potential. Depending on the time of vibratorypercussion loading, there is a decrease in the activated coals $\xi$-potential and negative charge of the coal surface.

Table 3 presents the values of the decrease in the electrostatic potential $\Delta \xi_{\max }$ depending on the time of vibratory-percussion impact.

Table 3. Change in the electrokinetic potential after vibratory-percussion activation of coal.

\begin{tabular}{|c|c|c|c|c|c|c|c|}
\hline$\Delta \xi_{\max }, \mathrm{mV}$ & -32.40 & -20.10 & -11.20 & -5.09 & 0 & 2.45 & 6.35 \\
\hline Time of loading, min & 0 & 10 & 20 & 30 & 40 & 50 & 60 \\
\hline
\end{tabular}

Thus, the experimental data results evidence that vibratory-percussion loading leads to compression of the double electric layer, that is, through transition of cations from the diffusion layer to the adsorption layer. A decrease in the $\xi$-potential has a significant influence on the ability of coal particles to hydration. The data in Table 3 show that when using the electrochemical method, the hydration ability of the coal surface decreases.

The second stage is aimed at obtaining gas hydrates using the activated coal of grade G. The paper studies the production of methane gas hydrate with a high content of hydrateforming gas in the solid phase in an isolated system at $T=274 \mathrm{~K}$ and a pressure of $5 \mathrm{MPa}$ with the presence in the chamber of mechanically activated coal samples.

The following three conditions are necessary for hydrate formation:

1. Favourable thermobaric conditions;

2. Presence of a hydrate-forming substance;

3. Certain amount of water.

The kinetic peculiarities of the methane gas hydrates formation in the presence of surfactants [30] have been studied, and these studies were also performed under various thermobaric conditions.

The time of occurrence of the ice crust first crystals is fixed $(T, \mathrm{~K})$. The amount of methane $\left(C_{m}\right)$ in gas hydrates is determined according to the described methodology [30]. The hydrate formation process can also be monitored through a transparent reactor window. Water is supplied to the chamber with activated coal simultaneously with gaseous methane through a choke-input. Thus, water is supplied to the reactor in the form of very small particles. Such an experimental scheme has its advantages, because, firstly, the temperature of a substance when passing through a choke, as a rule, decreases significantly due to the Joule-Thomson effect. Secondly, in a reduced flow area of the valve there is a high flow rate. Secondly, in a reduced opening area of a valve, a high flow velocity arises.

The thermobaric dependence curve of the gas hydrates production is shown in Fig. 1. As a result of the experiment, option has been chosen, using which the subsequent research on the thermobaric curve is performed. 


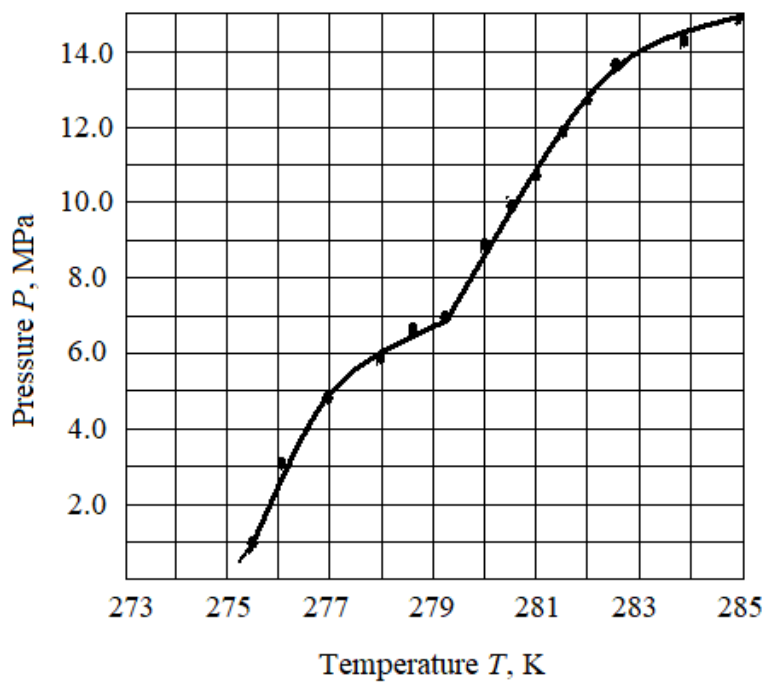

Fig. 1. Thermobaric curve of methane gas hydrates formation in a medium of activated coals.

As can be seen in Fig. 1, there is a strong slope on thermobaric curve of the methane gas hydrates formation in an activated coals medium. This is caused by the fact that gas hydrate of the KS-II structure is formed with various degrees of filling the cavities: from $275 \mathrm{~K}$ to $279.2 \mathrm{~K}$ - small cavities and higher - larger ones, as it is studied in the work [36].

Besides thermobaric curve, a research has been conducted on the determining the gaseous methane content per unit volume of methane hydrate depending on the time of hydrate formation in a medium of activated coals. Fig. 2 shows the experimental data according to the methodology in the work [30].

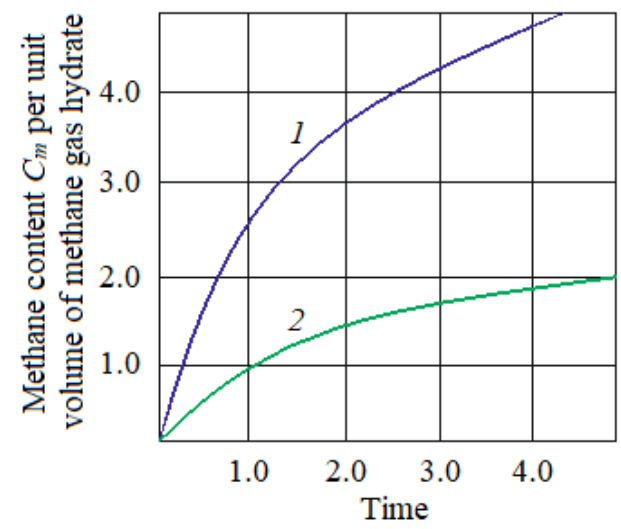

Fig. 2. Dependence of the gaseous methane content per unit volume of methane hydrate on the time of hydrate formation: 1 - in mechanically activated coal; 2 - without coal.

Thus, the volume of methane on the coal matrix is greater than that of gas hydrates formed under artificial conditions without activated additives.

In conclusion, Figure 3 shows the profiles of changes in the velocities of the new structural groups formation process during the methane gas hydrates formation on the coal surface. 


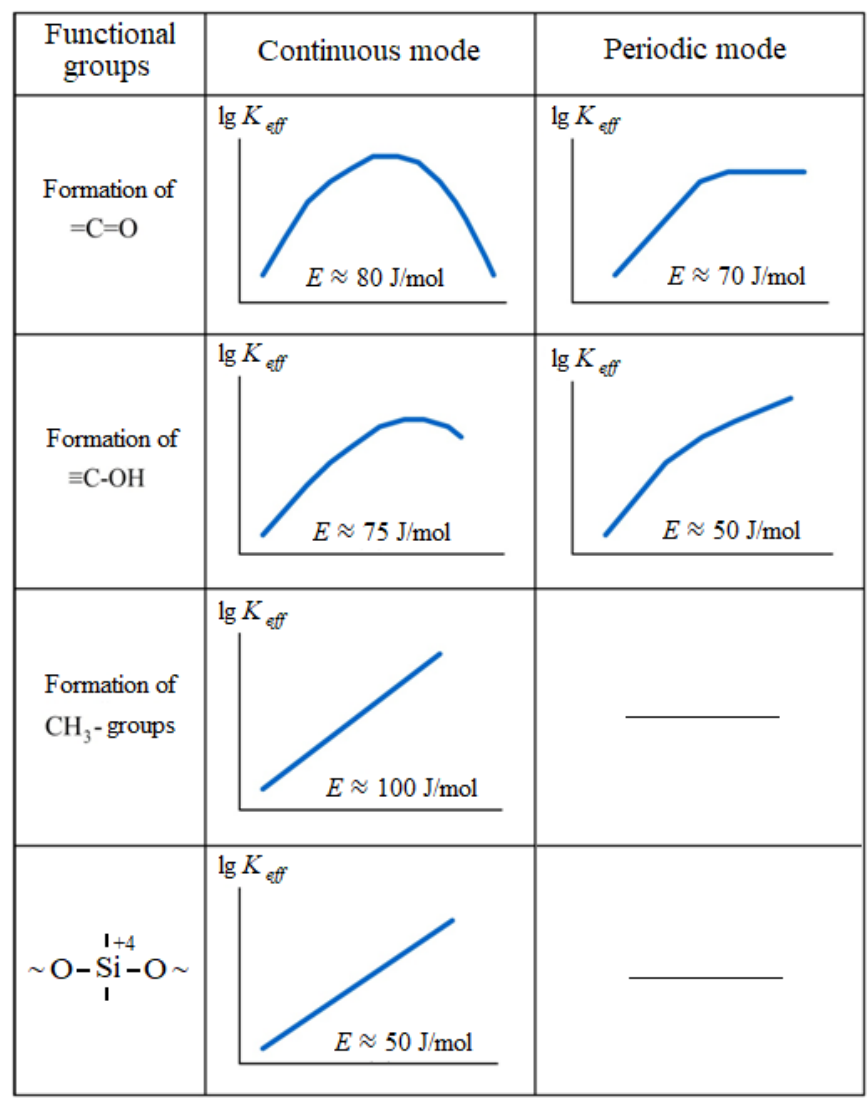

Fig. 3. The velocities of processes and the activation energy $E$ of these processes during the gas hydrates formation in a medium of activated coal.

The atomic groups formation and energies $E$ of the processes activation are determined by the slope of the initial section of the accumulation curves.

This evidences that the gas hydrates inclusions in the seams play a significant role in the processes leading to sudden outbursts of coal and gas, which are prone to develop in diametrically opposite directions. It is assumed that methane bonds with the coal matrix occur as a result of strong chemisorption, which, when thermobaric conditions are disturbed, leads to the gas-dynamic coal seams activity.

In coal seams, depending on thermodynamic conditions, natural gas can be in various states: free, sorbed, and solid like gas hydrates. Solid solutions may exist at certain temperatures and pressures. A phase transition of gas from a solid phase to a free one is possible provided that the phase parameters are more or less than equilibrium parameters. According to the concepts, described in $[36,37]$, this is possible when the preparatory mine working is sharply driven from the zone of hard coals into the zone of broken coals, which leads to an increase in mechanical stresses accompanied by a decrease in the volume of the pore space and, consequently, to an increase in gas pressure.

It has been determined experimentally that under certain thermodynamic conditions (temperature and pressure) and humidity, methane gas hydrates can be generated in the pore space of coal seams. In view of the small size of gas hydrate particles, their decomposition velocity is high enough and can reach up to $30 \mu \mathrm{m} / \mathrm{s}$ at $1-4 \mathrm{~nm}$. The gas hydrate particles decomposition occurs if the pressure in the gas - massif system at a 
certain temperature decrease or increase abruptly to values other than equilibrium ones. In such cases, the gas pressure in the area of decomposition may increase abruptly.

In this regard, it becomes clear where large volumes of gas come from in case of sudden outbursts, which exceed the volumes caused by the natural gas content of coal seams.

\section{Conclusions}

1. It has been revealed that during the gas hydrates formation in coal seams between the coal matrix and gaseous methane, "strong" chemisorption occurs.

2. It has been substantiated that during the dissociation of gas hydrates, obtained in a medium of activated coals, twice as much gaseous methane is released.

3. The solid solutions of natural gas in coal seams are formed at certain thermodynamic parameters $P$ and $T$ and natural humidity characteristic of coal seams, which are dangerous for sudden coal and gas outbursts. The gas hydrates dissociation significantly influences on the gas-dynamic activity of a coal seam and the formation of an outburst hazardous situation.

We express our gratitude to the staff of Pokrovskoe Mine Administration for providing the possibility to conduct experimental studies.

\section{References}

1. Kalyakin, S.A., Shevtsov, N.R., \& Kupenko, I.V. (2012). Sozdanie effektivnoy sistemy vzryvozashchity ugolnykh shakht. Ugol Ukrainy, (2), 24-30. Retrived from http://nbuv.gov.ua/UJRN/ugukr_2012_2_9

2. Bondarenko, V., Kovalevska, I., Lysenko, R., \& Malova, O. (2019). The XIII International Research and Practice Conference "Ukrainian School of Mining Engineering" as a step to the new direction of innovative technologies and intelligent systems in the mining industry. E3S Web of Conferences, (123), 00001. https://doi.org/10.1051/e3sconf/201912300001

3. Bondarenko, V., \& Dychkovskiy, R. (2006). Methods of extraction of thin and rather thin coal seams in the works of the scientists of the underground mining faculty (National Mining University). New Technological Solutions in Underground Mining International Mining Forum 2006, 21-25.

4. Bondarenko, V.I., Griadushchiy, Y.B., Dychkovskiy, R.O., Korz, P.P., \& Koval, O.I. (2007). Advanced experience and direction of mining of thin coal seams in Ukraine. Technical, Technological and Economic Aspects of Thin-Seams Coal Mining International Mining Forum 2007, 1-7.

5. Kostikov, R.R. (1995). Dvukhvalentnyy uglerod. Sorovskiy Obrazovatelnyy Zhurnal, (1), 67-73.

6. Shevtsov, N.R. (1992). Teoriya lokalizatsii vzryva, sposoby i sredstva vzryvozashchity gornykh vyrabotok pri vzryvnykh rabotakh. Ph.D. Thesis. Donetsk, Ukraine: IHTM.

7. Bondarenko, V.I., Kharin, Ye.N., Antoshchenko, N.I., \& Gasyuk, R.L. (2013). Basic scientific positions of forecast of the dynamics of methane release when mining the gas bearing coal seams. Naukovyi Visnyk Natsionalnoho Hirnychoho Universytetu, (5), 24-30.

8. Alexeev, A.D., \& Vasylenko, T.A., \& Ulyanova, E.V. (2004). Phase states of methane in fossil coals. Solid state communications, 130(10), 669-673. https://doi.org/10.1016/j.ssc.2004.03.034

9. Bondarenko, V., Kovalevska, I., \& Ganushevych, K. (2014). Progressive technologies of coal, coalbed methane, and ores mining. The Netherlands, Leiden: CRC Press/Balkema. https://doi.org/10.1201/b17547

10. Ayruni, A.T. (1987). Prognozirovanie i predotvrashchenie gazodinamicheskikh yavleniy $v$ ugol'nykh shakhtakh. Moskva: Nauka, 310. 
11. Law, B.E., Ulmishek, G.F., Clayton, J.L., Kabyshev, B.P., Pashova, N.T., \& Krivosheya, V.A. (1998). Basin-centered gas evaluated in Dnieper-Donets basin, Donbas foldbelt, Ukraine. Oil and Gas Journal, 96(47), 74-78.

12. Sribna, Y., Trokhymets, O., Nosatov, I., \& Kriukova, I. (2019). The globalization of the world coal market - contradictions and trends. E3S Web of Conferences, (123), 01044. https://doi.org/10.1051/e3sconf/201912301044

13. Makogon, Yu.F., \& Morozov, I.F. (1973). Vnezapnye vybrosy i uchastie v nikh metana v gidratnom sostoyanii. Bezopasnost' truda v promyshlennosti, (12), 36-37.

14. Makogon, Yu.F. (2003). Prirodnye gazovye gidraty: rasprostranenie, modeli obrazovaniya, resursy. Rossiyskiy Khimicheskiy Zhurnal, 48(3), 70-79.

15. Bondarenko, V., Sai, K., Prokopenko, K., \& Zhuravlov, D. (2018). Thermodynamic and geomechanical processes research in the development of gas hydrate deposits in the conditions of the Black Sea. Mining of Mineral Deposits, 12(2), 104-115. https://doi.org/10.15407/mining12.02.104

16. Bondarenko, V.I., \& Sai, K.S. (2018). Process pattern of heterogeneous gas hydrate deposits dissociation. Naukovyi Visnyk Natsionalnoho Hirnychoho Universytetu, (2), 21-28. https://doi.org/10.29202/nvngu/2018-2/4

17. Aregbe, A.G. (2017). Gas hydrate - properties, formation and benefits. Open Journal of Yangtze Oil and Gas, 2(1), 27-44. https://doi.org/10.4236/ojogas.2017.21003

18. Giricheva, N.I., Ishchenko, A.A., Yusupov, V.I., Bagratashvili, V.N., \& Girichev, G.V. (2014). Struktura i energetika metanovykh gidratov. Izvestiya Vysshikh Uchebnykh Zavedeniy. Seriya: Khimiya i Khimicheskaya Tekhnologiya, 57(9), 3-9.

19. Dyrdin, V.V., Smirnov, V.G., \& Shepeleva, S.A. (2013). Parameters of Methane Condition during Phase Transitionat the Outburst-Hazardous Coal Seam Edges. Journal of Mining Science, 49(6), 908-912. https://doi.org/10.1134/S1062739149060099

20. Smirnov, V.G., $\quad$ Manakov, A.Yu., $\quad$ Ukraintseva, E.A, Villevald, G.V., $\quad$ Karpova, T.D., Dyrdin, V.V., Lyrshchikov, S.Yu., Ismagilov, Z.R., Terekhova, I.S., \& Ogienko, A.G. (2016). Formation and decomposition of methane hydrate in coal. Fuel, (166), 188-195. https://doi.org/10.1016/i.fuel.2015.10.123

21. Smirnov, V.G., Manakov, A.Ju., Dyrdin, V.V., \& Ismagilov, Z.R. (2017). Formirovanie gidratov metana $\mathrm{v}$ prirodnom ugle. Vestnik Nauchnogo Tsentra po Bezopasnosti Rabot v Ugolnoy promyshlennosti, (1), 13-25.

22. Smirnov, V.G., Dyrdin, V.V., Ismagilov, Z.R., Kim, T.L., \& Manakov, A.Ju. (2017). O vliyanii form svyazi metana $\mathrm{s}$ ugolnoy matritsey na gazodinamicheskie yavleniya, voznikayushhie pri podzemnoy razrabotke ugolnykh plastov. Vestnik Nauchnogo Tsentra po Bezopasnosti Rabot $v$ Ugolny Promyshlennosti, (1), 34-41.

23. Hanushevych, K., \& Srivastava, V. (2017). Coalbed methane: places of origin, perspectives of extraction, alternative methods of transportation with the use of gas hydrate and nanotechnologies. Mining of Mineral Deposits, 11(3), 23-33. https://doi.org/10.15407/mining11.03.023

24. Kalacheva, L. P., \& Rozhin, I. I. (2017). The influence of the chloride-calcium-type water composition on the properties of natural gas hydrates. Neftegazovaya Geologiya. Teoriya $i$ Praktika, 12(3), 1-13. https://doi.org/10.17353/2070-5379/25_2017

25. Kobolev, V. (2017). Structural, tectonic and fluid-dynamic aspects of deep degassing of the black sea megatrench. Mining of Mineral Deposits, 11(1), 31-49. https://doi.org/10.15407/mining11.01.031

26. Maksymova, E., Ovchynnikov, M., Lysenko, R., \& Kostrytska, S. (2018). Physical and chemical methods of methane utilization in Ukrainian coal mines. Solid State Phenomena, (277), 147-156. https://doi.org/10.4028/www.scientific.net/SSP.277.147

27. Bondarenko, V., Svietkina, O., \& Sai, K. (2018). Effect of mechanoactivated hemical additives on the process of gas hydrate formation. Eastern-European Journal of Enterprise Technologies, 1(6(91)), 17-26. https://doi.org/10.15587/1729-4061.2018.123885 
28. Ovchynnikov, M., Ganushevych, K., \& Sai, K. (2013). Methodology of gas hydrates formation from gaseous mixtures of various compositions. Annual Scientific-Technical Collection - Mining of Mineral Deposits 2013, 203-205. https://doi.org/10.1201/b16354-37

29. Bondarenko, V., Sai, K., Ganushevych, K., \& Ovchynnikov, M. (2015). The results of gas hydrates process research in porous media. New Developments in Mining Engineering 2015: Theoretical and Practical Solutions of Mineral Resources Mining, 123-127. https://doi.org/10.1201/b19901

30. Bondarenko, V., Svietkina, O., \& \& Sai, K. (2017). Study of the formation mechanism of gas hydrates of methane in the presence of surface-active substances. Eastern-European Journal of Enterprise Technologies, 5(6(89)), 48-55. https://doi.org/10.15587/1729-4061.2017.112313

31. Kuzmenko, O.M., \& Petlovanyi, M.V. (2015). Substantiation the expediency of fine gridding of cementing material during backfill works. Mining of Mineral Deposits, 9(2), 183-190. https://doi.org/10.15407/mining09.02.183

32. Svetkina, E.Yu., \& Petlovanyi, M.V. (2012). Zakonomernosti formirovaniya struktury i prochnosti tverdeyushchey zakladki pri raznoy dispersnosti vyazhushchego materiala. Zbirnyk Naukovykh Prats Natsionalnoho Hirnychoho Universytetu, (37), 80-86.

33. Opredelenie udelnoy poverkhnosti poroshkov po soprotivleniyu filtratsii razrezhennogo gaza. Metodika opredeleniya. (1979). Moskva: AN SSSR.

34. Kuzmenko, O., Petlyovanyy, M., \& Stupnik, M. (2013). The influence of fine particles of binding materials on the strength properties of hardening backfill. Annual Scientific-Technical CollectionMining of Mineral Deposits 2013, 45-48. https://doi.org/10.1201/b16354-10

35. Korsakov, V.G., Shelomentseva, I.V., Yur'yevskaya, I.M., \& Petrova, L.I. (1983). Issledovanie energeticheskikh kharakteristik i prognozirovanie fiziko-khimicheskikh i tekhnicheskikh svoystv materialov. Napravlennyy sintez tverdykh veshchestv, (1), 158-174.

36. Subbotin, O.S., $\quad$ Adamov, T.P., $\quad$ Belosludov, R.V., $\quad$ Mizuseki, Ch., $\quad$ Kavazoje, Jo., $\quad$ \& Belosludov, V.R. (2012). Teoretichekoe issledovanie usloviy obrazovaniya gidratov ozona. Zhurnal Strukturnoy Khimii, 53(4), 640-646.

37. Vylezhagin, V.N., Egorov, P.V., \& Murashev, V.I. (1990). Strukturnye modeli gornogo massiva v mekhanizme geomekhanicheskikh protsessov. Novosibirsk: Nauka, 291. 